\title{
根太と直交する部材を有するスチールハウス床の重量床衝撃音遮断性の評価

\author{
EVALUATION OF HEAVY-WEIGHT FLOOR IMPACT SOUND INSULATION PERFORMANCE \\ OF COLD-FORMED STEEL FRAMED HOUSE WITH LATTICE-ARRAYED FLOOR JOISTS
}

\author{
中安誠明*1, 海原広幸*1, 半谷公司*2, 高橋大弐*3 \\ Nariaki NAKAYASU, Hiroyuki KAIBARA, Koji HANYA \\ and Daiji TAKAHASHI
}

\begin{abstract}
The number of cold-formed steel framed houses is increasing and they tend to be built as apartment houses rather than detached houses. Along with this trend, heavy-floor impact sound insulation performance of the houses is expected to be improved. In order to meet this expectation, experimental test and numerical analysis are carried out, using the really-constructed houses as specimens. The results indicate, 1) in order to improve the heavy-floor impact sound insulation performance of cold-formed steel framed houses, sound pressure in a frequency band of $63 \mathrm{~Hz}$ has to be reduced, 2) floors of cold-formed steel houses tend to vibrate in a perpendicular direction to floor joists axis in the low-ranged frequency band, which is caused by the anisotropy of floor bending stiffness, 3) considering the vibrating mode shape, to improve sound insulation performance, it seems one of the solutions to increase the floor bending stiffness of weak axis, and 4) the possibility of the suggested solution is confirmed through the on-site test.
\end{abstract}

Keywords: Cold-Formed Steel Framed House, Heavy-Weight Floor Impact Sound, Lattice-Arrayed Floor Joists, On-site Test, Numerical Analysis スチールハウス, 重量床衝撃音, 直交根太, 実大実験, 数值解析

\section{1. はじめに}

スチールハウス 1)や2)など（図 1）は、木造ツーバイフォーの木枠を

厚さ $2.3 \mathrm{~mm}$ 未満の泠間成形の溶融亜鉛めっき形鋼で置き換えた薄 板軽量形鋼造の住宅であり、国内では 2001 年に同構造に関する技 術基準が公布されて以降、戸建住宅や共同住宅としての実物件が建 設されてきている。また、構造や環境といった各種技術分野での調 查や研究開発が進められてきている。

スチールハウスの音環境分野の性能のうち、重量床衝撃音の遮断 性は、前記基準の公布から、独立天井の採用や面材仕様の強化によ る改善がなされてきている ${ }^{3)}$ 、4)など。現行の一般的な仕様で、JIS A 1419-2 に準拠した評価で L-65 の性能が達成されているが、近年、 共同住宅として採用される機会が増えていることから、性能の更な る向上が求められている。

重量床衝撃音の遮断性を向上寸る方法として、例えば文献 5)では、 スチールハウスの床根太の中に水砕スラグや転炉スラグなどからな る粒状体 6),77なとを設置して、粒状体の制振効果に期待して性能を向 上寸る方法が検討されている。同文献内では、粒状体の種類や充填 量を変数とした検討の結果が示されている。

また別の方法として、文献 8)や9)では、スチールハウスのような 1 方向に根太が配される床構造において、床の面外の曲げ剛性が強 軸方向と弱軸方向で異なる点を踏まえ、根太床の部材構成に注目し て、根太スパン方向と直交する方向にころび止めやふれ止めを設置
し、弱軸方向の曲げ剛性を増加させて性能を向上する方法が検討さ れている。ころび止めやふれ止めの断面や配置を変数とした検討の 結果として、検討対象の部材構成の範囲内では、弱軸方向の曲げ岡 性を十分に向上することができず、重量床衝撃音の遮断性を向上す ることは困難であるため、面材の質量増加といった他の方法の検討 が有効であるといった見解が示されている。

ここで文献 8)や9)に注目すると、これら検討の当初の方針は、面 材の質量増加だけでなく、床の面外曲げ剛性の向上とあわせて、遮 音性を確保することであった。根太や他部材の断面や配置を工夫し

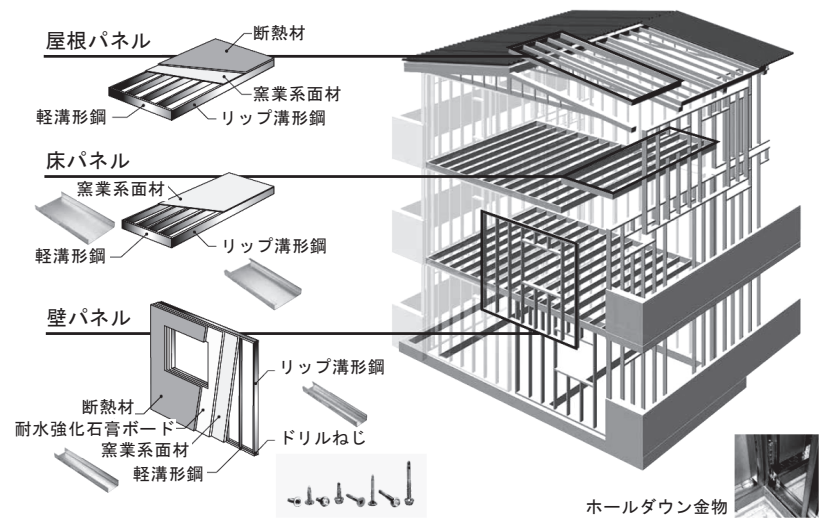

図 1 薄板軽量形鋼造としてのスチールハウス
*1 新日鐵住金(株) 工修

$* 2$ 新日鐵住金(侏) 工博

*3 京都大学大学院工学研究科建築学専攻 教授. 工博
Nippon Steel \& Sumitomo Metal Corporation, M.Eng.

Nippon Steel \& Sumitomo Metal Corporation, Dr.Eng.

Prof., Dept. of Architecture and Architectural Engineering, Kyoto University, Dr.Eng. 
て、床の曲げ剛性を向上する対策によってスチールハウスの重量床 衝撃音の遮断性を向上することができれば、床の質量の増加を抑制 しながら、粒状体といった新規の材料を追加することもなく、現行 仕様の部材構成の比較的簡易な改良によって、経済効率の良い遮音 対策が実現できる可能性がある。

そこで本報では、文献 8)や 9)を参考に、根太スパン方向と直交す る方向に部材を追加することによる重量床衝撃音の遮断性の向上の 可能性を探索すべく、同対策を施したスチールハウス床の性能の評 価に取組む。具体的には、まずは実物件を対象に、現行のスチール 八ウスの重量床衝撃音の遮断性と振動特性を実験と数值解析により 調查し、重量床衝撃音の周波数特性、遮音性能の決定周波数、およ び同周波数における床の振動特性を把握する。次に、根太の構成と 曲げ剛性の相関を数值解析により調查し、根太と直交する部材の追 加による床の面外曲げ剛性の向上の程度を評価する。最後に、根太 と直交する部材を追加して曲げ剛性を向上した床について、実物件 での重量床衝撃音の遮断性を実験により評価して、根太と直交する 部材により曲げ剛性を向上させて重量床衝撃音の遮断性を改善する 可能性を探索する。以下にその内容を示す。

\section{2. 現行床（軽角形鋼仕様）の重量床衝撃音の遮断性と振動性状}

本章では、実物件を対象に、現行のスチールハウスの重量床衝撃 音の遮断性と振動性状を実験と数值解析により調查する。

\section{1. 調査対象の床}

図 2 に調查対象の物件の外観、図 3 に調查時の様子、図 4 と図 5 に調查対象の床の平面図、根太伏図、断面図、および表 1 に調查対 象の床の仕様を示す。表 1 中の部材は、実物件で積層する順に上か ら下に記載している。調查対象の物件は 3 階建て、全 45 戸、独身 者向けの共同住宅で、床根太が 1 方向に配置され、現行のスチール 八ウスの標準的な仕様の一つを有するものである。調查対象の床は 2 階の 1 室で、同床は根太スパンが $3,185 \mathrm{~mm}$ 、根太直交方向スパン が 3,640mm である。床根太は、断面が 235BW12（口-235x50x1.2） で、スパン直交方向に $455 \mathrm{~mm}$ の間隔で配される。仕上材は、施工 完了時の仕様として、床上に乾式二重床、床下に独立天井 140LCW10（C-140x50x12x1.0）が設置される。

なお、本報において、薄板軽量形鋼の断面は「断面形状-断面寸法 や板厚」として表現することする。例えば $\square-235 \times 50 x 1.2$ は、断面 形状が軽角形鋼で、断面高さが $235 \mathrm{~mm}$ 、断面幅が $50 \mathrm{~mm}$ 、板厚が 1.2mm であり、C-140x50x12x1.0 は、断面形状がリップ溝形鋼で、 断面高さが $140 \mathrm{~mm}$ 、断面幅が $50 \mathrm{~mm}$ 、リップ高さが $12 \mathrm{~mm}$ 、板厚 が $1.2 \mathrm{~mm}$ であることを示す。

\section{2. 現行床（軽角形鋼仕様）の重量床衝撃音の遮断性の実験調査}

\subsection{1. 実験計画}

調査は表 1 に記載の施工段階別に行い、床躯体のみが施工される 第 1 段階、床躯体と天井が施工される第 2 段階、および前記に加え て乾式二重床が施工される第 3 段階で実施する。同表中、のの部材 は、各段階において施工済みのものを示す。

加振と計測は JIS A 1418-2 に準拠して行う。加振源は標準重量衝 撃源（タイヤ）とし、加振点と計測点の平面位置は、それぞれ 2 階 と 1 階の室内において、床中央点と対角線の 4 等分点 4 点からなる 5 点とする (図 4 中の○部)。各計測点の結果をエネルギー平均し、
各加振点の結果を算術平均して重量床衝撃音の遮断性を評価する。 重量床衝撃音の遮断性能の評価は、JIS A 1419-2 の附属書記載の等 級曲線を用いて行うこととする。

\subsection{2. 実験結果}

図 6 に、施工段階別の現行のスチールハウス床の重量床衝撃音の 遮断性の調査結果を示寸。同図から、施工段階が進むにつれて衝撃 音の遮断性が向上寸る傾向があることがわかる。JIS A 1419-2 の等 級曲線を参照すると、各施工段階とも $63 \mathrm{~Hz}$ 帯域が衝撃音の遮断性 能の決定周波数となっており、同帯域の音圧レベルは、第 1 段階で $99.7 \mathrm{~dB}$ 、第 2 段階で $91.9 \mathrm{~dB}$ 、および第 3 段階で $88.0 \mathrm{~dB}$ となって いる。同図の各施工段階の差異から、独立天井の設置により $7.8 \mathrm{~dB}$ 、 乾式二重床の設置により $3.9 \mathrm{~dB}$ の性能の改善が得られることがわか る。一方、第 2 段階から第 3 段階への移行に際しては、乾式二重床 の施工により、250や $500 \mathrm{~Hz}$ 帯域の性能が悪化する傾向が見られる。

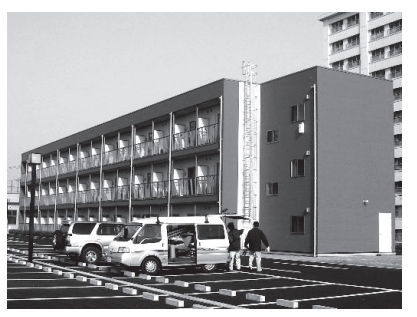

図 2 調査対象の外観

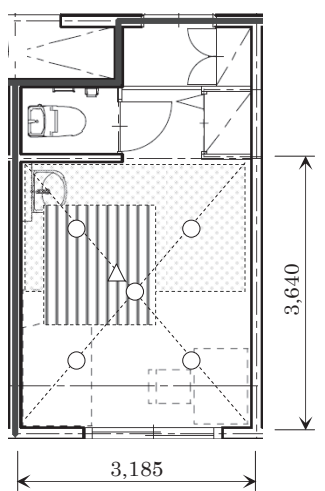



図 3 調査時の様子

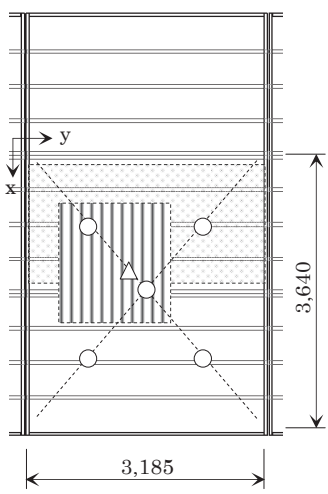

図 4 調査対象の床の平面図（左）と根太伏図（右）

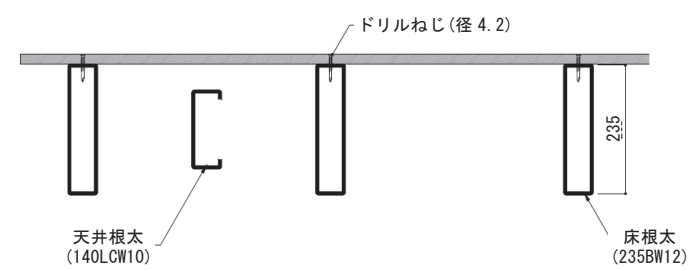

図 5 調査対象の床の断面図

表 1 調査対象の床の仕様

\begin{tabular}{|c|c|c|c|c|c|c|c|c|}
\hline \multicolumn{3}{|c|}{ 構成部材 } & \multicolumn{3}{|c|}{ 施工段階 } & \multicolumn{3}{|c|}{ 材料物性（数值解析用） } \\
\hline & 仕様 & $\begin{array}{l}\text { 重量 } \\
\mathrm{kg} / \mathrm{m}^{2}\end{array}$ & 1 & 2 & 3 & 比重 & $\begin{array}{c}\text { やング係数 } \\
\mathrm{N} / \mathrm{mm}^{2}\end{array}$ & ポアリン 比 \\
\hline \multirow[t]{2}{*}{ 二重床 } & フローリング $12 \mathrm{~mm}$ & 6.0 & - & - & 0 & - & - & - \\
\hline & ペーティタルボード $20 \mathrm{~mm}$ & 14.0 & - & - & ? & - & - & - \\
\hline \multirow[t]{4}{*}{ 床躯体 } & 捨て合板 $12 \mathrm{~mm}$ & 6.0 & - & - & $\overline{0}$ & 0.60 & 6,000 & 0.30 \\
\hline & 普通石膏ボード $15 \mathrm{~mm} \mathrm{x2}$ & 21.0 & - & - & - & 0.75 & 1,800 & 0.20 \\
\hline & 硬質木片セメン板 $18 \mathrm{~mm}$ & 10.8 & - & - & - & 0.95 & 4,400 & 0.30 \\
\hline & 床根太235BW12@455 & 11.6 & - & - & ? & 7.85 & 205,000 & 0.30 \\
\hline \multirow[t]{3}{*}{ 独立天井 } & 天井根太140LCW10@910 & 2.2 & - & - & ๑ & - & - & - \\
\hline & 口ック多ール40kg $/ \mathrm{m}^{3} 50 \mathrm{~mm}$ & 2.0 & - & - & 0 & - & - & - \\
\hline & 強化石膏ボード $12.5 \mathrm{~mm} \times 2$ & 20.0 & - & - & 0 & - & - & - \\
\hline
\end{tabular}




\subsection{3. 実験結果の分析}

\section{(1) 独立天井の遮音効果}

図 7 に、第 1 段階の音圧レベルの計測結果から第 2 段階の音圧レ ベルの計測結果を差し引いたものと、文献 10)記載の石膏ボード $12 \mathrm{~mm}$ の 2 枚積層板の透過損失を比較して示す。図 7 の横軸が $1 / 3$ オクターブバンドのグラフ中の透過損失の值は、文献に従い、 $100 \mathrm{~Hz}$ 以上の範囲を示す。ここで図 7 の横軸がオクターブバンドのグラフ 中の值は、同図の横軸が $1 / 3$ オクターブバンドのグラフ中の值の $\mathrm{dB}$ 和として算出している。

同図から、強化石膏ボード 2 枚で構成される天井板の遮音効果は、 $160 \mathrm{~Hz}$ 帯域以上の周波数範囲において、石膏ボード $12 \mathrm{~mm}$ の 2 枚 積層板の透過損失よりも小さくなる傾向があることがわかる。また、 石膏ボードの透過損失の勾配が、125〜 $500 \mathrm{~Hz}$ 帯域の平均の $5.4 \mathrm{~dB} / \mathrm{Oct}$ 程度で代表可能と仮定すると、31.5 63Hz 帯域において は、天井板の遮音効果は石膏ボードの透過損失と比較して、 $160 \mathrm{~Hz}$ 帯域以上の周波数範囲ほどには小さくはなっていないと推測される。

$160 \mathrm{~Hz}$ 帯域以上の範囲において天井板の遮音効果が小さくなる 原因の 1 つとして、床根太の固体振動が端根太を介して独立天井根 太に伝播する現象が生じていることが考えられる。同現象が生じて いる場合、端根太と独立天井根太や、独立天井根太と天井板の吊り ボルトの絶縁対策により、遮音性が向上する可能性があるといえる。

\section{(2) 空気層の共振の影響}

天井や二重床を設置する場合、空気層をばねとする振動系の共振 により遮音性能が低下寸ることが懸念される。調査対象の床におけ る共振の影響を調べるため、式(1)、および(2)〜 (5)を用いて共振周 波数を算定する。式(1)は 2 枚の面材の間に挟まれる 1 つの空気層か らなる 2 質点 1 自由度系を想定するもの、式(2)〜 (5) は 3 枚の面材 の間に挟まれる 2 つの空気層からなる 3 質点 2 自由度系を想定する

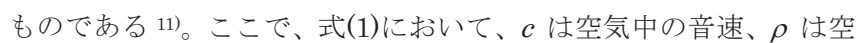
気の比重、 $l_{0}$ は空気層の厚さ、 $m_{1} 、 m_{2}$ は空気層の上下の部材の面 密度を示寸。また式(2)において、 $m_{3} 、 m_{4} 、 m_{5}$ は空気層の上下の部 材の面密度、 $l_{1}$ は面密度が $m_{3}$ と $m_{4}$ の部材の間の空気層の厚さ、 $l_{2}$ は面密度が $m_{4}$ と $m_{5}$ の部材の間の空気層の厚さを示す。

$$
\begin{aligned}
& f_{r 1}=\frac{c}{2 \pi} \cdot \sqrt{\frac{\rho}{l_{0}} \cdot \frac{m_{1}+m_{2}}{m_{1} \cdot m_{2}}} \\
& f_{r 2,3}=\frac{\sqrt{2}}{4 \pi} \cdot \sqrt{\frac{\lambda_{1}+\lambda_{2} \mp \sqrt{(}}{\lambda_{1}}}=\kappa_{1} \cdot m_{5} \cdot\left(m_{3}+m_{4}\right) \\
& \lambda_{2}=\kappa_{2} \cdot m_{3} \cdot\left(m_{4}+m_{5}\right) \\
& \kappa_{1,2}=\frac{\rho \cdot c^{2}}{l_{1,2}}
\end{aligned}
$$$$
f_{r 2,3}=\frac{\sqrt{2}}{4 \pi} \cdot \sqrt{\frac{\lambda_{1}+\lambda_{2} \mp \sqrt{\left(\lambda_{1}-\lambda_{2}\right)^{2}+4 \cdot \kappa_{1} \cdot \kappa_{2} \cdot m_{3}^{2} \cdot m_{5}^{2}}}{m_{3} \cdot m_{4} \cdot m_{5}}}
$$

空気層をばねとする振動系として、(1)床躯体-空気層（厚さ $390 \mathrm{~mm}$ ）-独立天井、(2)二重床-空気層（厚さ $63 \mathrm{~mm}$ ）-床躯体、お よび(3)二重床-空気層（厚さ $63 \mathrm{~mm}$ ）-床躯体-空気層（厚さ $390 \mathrm{~mm}$ ） 一独立天井の 3 種類を想定する。各々の振動数は、式(1)より、振動 系(1)で $23 \mathrm{~Hz}$ 、(2)で $63 \mathrm{~Hz}$ 、および式(2) (5)より、振動系(3)で $21 \mathrm{~Hz}$ と $63 \mathrm{~Hz}$ と計算される。
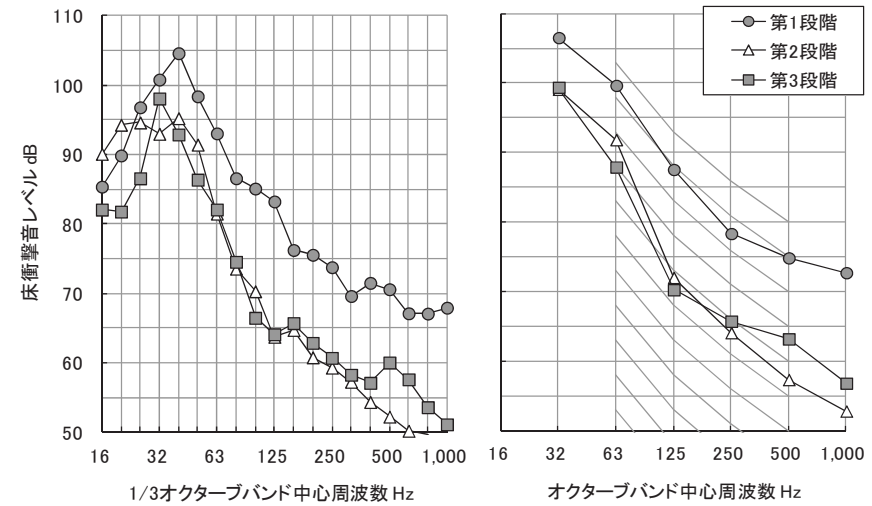

図 6 施工段階別の現行床の重量床衝撃音遮断性の比較
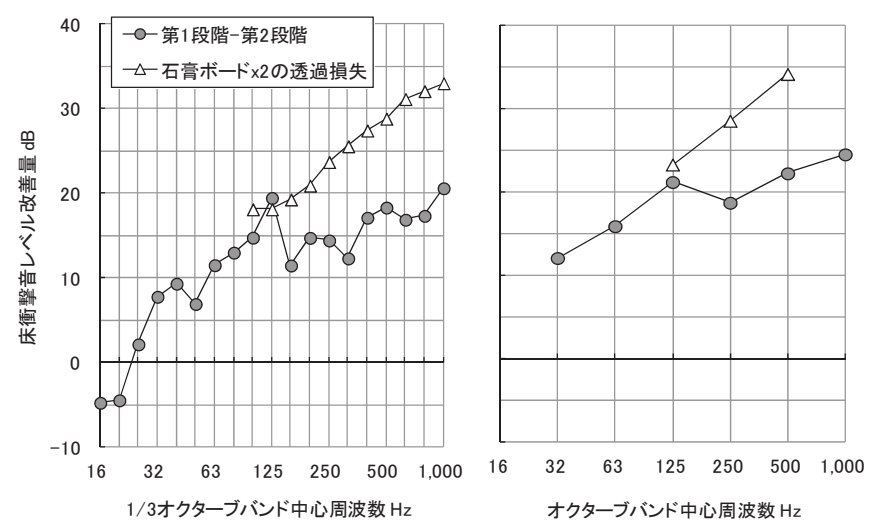

図 7 独立天井の遮音効果と石膏ボードの透過損失の比較

図 6 の第 1 段階と第 2 段階の比較から、振動系(1)の振動数を含む $25 \mathrm{~Hz}$ 帯域において、同帯域以上の範囲よりも両段階の差異が小さ くなる傾向があることがわかる。前述の計算結果を踏まえると、差 異が小さくなる原因の 1 つとして、天井懐の空気層をばねとする振 動系(1)の共振の影響が考えられる。なお、この振動系は、その振動 数が JIS A 1419-2 の等級曲線で重量床衝撃音の評価の対象となる 周波数よりも低い範囲にあるため、同評価に及ぼす影響は小さいと いえる。

一方、図 6 の第 2 段階と第 3 段階の比較から、振動系(2)や、振動 系(3)のうちの二重床の空気層が主体となるモードの振動数を含む $63 \mathrm{~Hz}$ 帯域において、同帯域と前後の帯域で明確な差異は確認でき ないことがわかる。今回調査対象の床において、二重床については、 少なくとも空気層をばねとする振動系を上記の方法で想定する場合 において、その共振の影響は確認できないといえる。

以上から、現行の独立天井や乾式二重床の設置により $4 \sim 8 \mathrm{~dB}$ の 重量床衝撃音レベルの改善が得られている一方、空気層をばねとす る共振の影響は見られていないことがわかり、更なる性能の改善に は、少なくとも空気層をばねとする振動系の共振回避によることは 難しいといえ、例えば天井や二重床の防振化や本報で検討する床の 高剛性化などの改良を検討する必要があるといえる。

\section{3. 現行床（軽角形鋼仕様）の振動性状の実験調査}

3 つの施工段階のいずれにおいても、JIS A 1419-2 の等級曲線を 参照すると、重量床衝撃音の決定周波数が $63 \mathrm{~Hz}$ 帯域となっている という前節の結果を踏まえ、本節では、同周波数帯域における床の 振動性状を実験により調査する。 


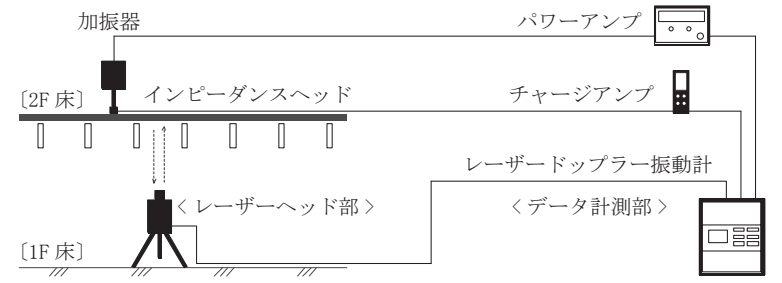

図 8 加振と計測の系列
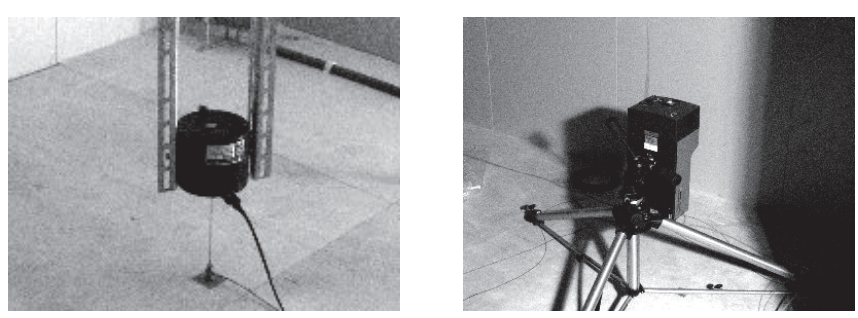

図 9 加振と計測の様子（左：床上の加振、右：床下の計測）

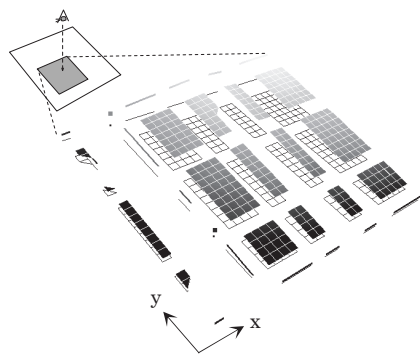

(a) 1 次モード : $43 \mathrm{~Hz}$

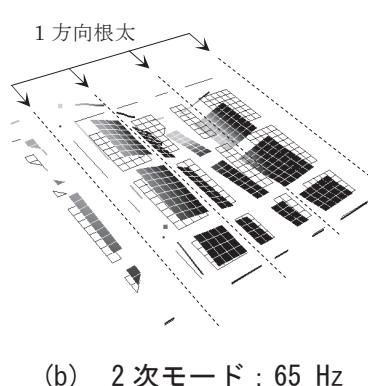

(b) 2 次モード : $65 \mathrm{~Hz}$

図 10 現行床の実験モード解析の結果

\subsection{1. 実験計画}

床躯体のみが施工される第 1 段階を対象に、実験モード解析 12) による調査を行う。

図 8 に加振と計測の系列、図 9 に加振と計測の様子を示す。加振 は、電磁式加振器を用いて行い、加振点は床上の 1 点とする（図 4 中の $\triangle$ 部)。計測は、スキャン式のレーザードップラー振動計を用い て行い、計測点は、床面の対称性を考慮して、床面の $1 / 4$ の範囲の 約 500 点とする (図 4 中の縦線部)。計測対象は根太スパン方向 $1,500 \mathrm{~mm}$ 、同直交方向 $1,600 \mathrm{~mm}$ の範囲の床面とする。床面の振動 に注目寸るため、床根太や独立天井根太、野縁受け、野縁といった 金物の下面は計測対象から除く。前記範囲に対し、根太スパン方向 に最大で 24 点、根太直交方向に最大で 21 点を計測する。計測点の 間隔は各方向で $60 \mathrm{~mm} \sim 80 \mathrm{~mm}$ 程度としている。

\subsection{2. 実験結果}

図 10 に、実験モード解析の結果として、1 次と 2 次の振動モード の振動数とモード形状を示す。計測は床下から行っているが、同図 中のモード形状の表示は床上から見下ろすアングルとしている。

同図から、1 次モードは $43 \mathrm{~Hz}$ であり、重量床衝撃音の評価範囲 の下限值の近傍であるとともに、2 次モードは $65 \mathrm{~Hz}$ であり、同範 囲内であることがわかる。また、1 次モードは床中央部に腹を 1 つ 有するモードであり、2 次モードは根太スパン方向と直交する方向 に腹が増えて高次化するモードであることがわかる。このような振 動性状を有する理由は、1 方向に根太を有するスチールハウス床が 面外の曲げ剛性に関して異方性を有し、図 10 中に記載の軸に関し て、x 軸回りの曲げに対しては剛性が高いが、y 軸回りの曲げに対

しては剛性が低いことによると考える。なお、このスチールハウス 床の振動性状は、同じように 1 方向に根太を有する木造床 13)なとと同 等といえる。

本節の結果から、現行のスチールハウスでは、重量床衝撃音の遮 断性の決定周波数となる $63 \mathrm{~Hz}$ 帯域において、根太スパン方向と直 交する方向に腹が増えて振動する傾向があるため、根太スパン方向 と直交する方向に部材を配置し、床の弱軸方向の曲げ剛性を向上し てこの振動を抑制できれば、重量床衝撃音の遮断性を向上できる可 能性があるといえる。

\section{4. 現行床（軽角形鋼仕様）の振動性状の数値解析調查}

前節の結果を踏まえ、本節では、実験で確認された振動性状の数 值解析による再現に取り組む。

\subsection{1. 解析計画}

図 11(a)に、解析モデルの概要を示す。前出の表 1 中に、解析に 用いる材料物性を示している。解析手法は有限要素法とし、汎用解 析プログラムの MSC.Marc を用いる。解析種別は、振動固有值解析 と寸る。解析の対象は、床面の対称性を考慮し、床面の $1 / 2$ の範囲 とする (図 4 中の網掛部)。床面材と形鋼の要素は双 1 次厚肉シェ ルとする。要素サイズは $100 \mathrm{~mm}$ 程度とし、要素数は 8,000 程度と なっている。

床面材は、表 1 記載の 4 枚について、積層する順番と各面材の板 厚を考慮し、各面材が実施工時において形鋼から離間する距離を解 析においてもオフセットさせてモデル化する（図 11(b)）。面材と面 材の結合には前記解析プログラムの Composite オプションを用い、 また面材と形鋼、形鋼と形鋼の接触部には Glue オプション 14)を用 いて、接触している範囲の変位を共有させるモデルとしている。

床の境界条件は、図 11(a)中において、実線部は壁で支持される ことを想定して、形鋼の上下フランジとウェブの交線において鉛直 方向の変位を拘束する。点線部には対称条件を付与する。また、無 線部は室内の通路部分で壁に支持されていない範囲であるため、形 鋼、面材ともに拘束条件を付与しない。結果として床パネルは、無 線部を除き、単純支持（鉛直方向の変位のみを拘束、水平方向の変 位とモーメントは非拘束) されている。図 11(c)に、同図(a)中の A

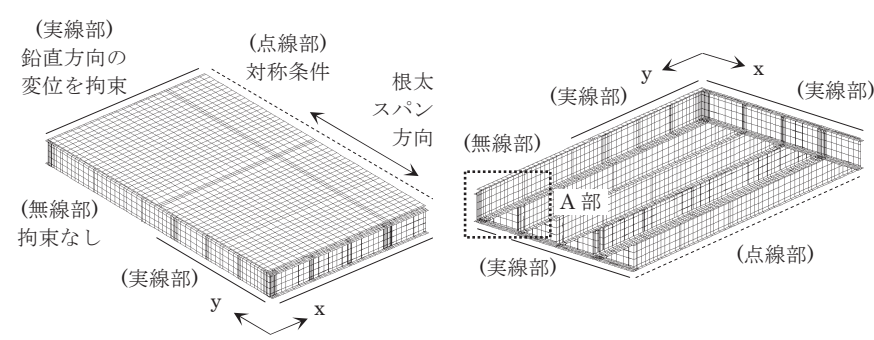

（a）モデルの概要

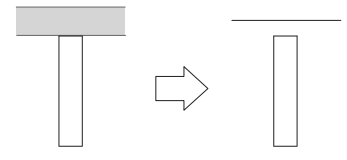

(b) 面材の板厚分だけ 形鋼からオフセットさせて モデル化するイメージ

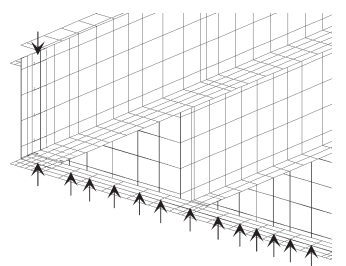

(c) A 部における 鉛直方向の変位の拘束
図 11 現行床（軽角形鋼仕様）の解析モデル 


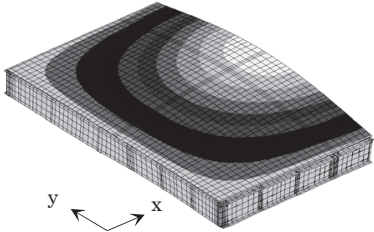

(a-1) 1 次モード : $45 \mathrm{~Hz}$

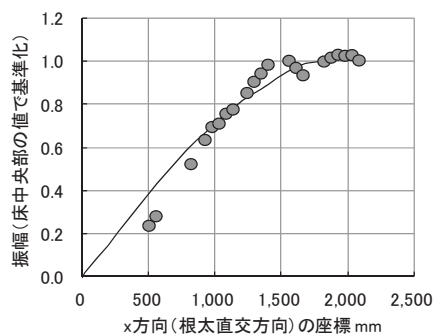

×方向( 根太直交方向) の座標 $\mathrm{mm}$

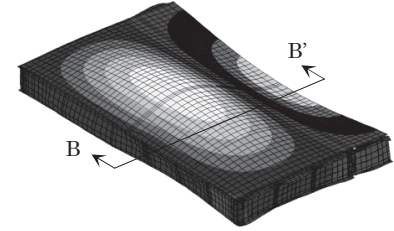

(a-2) 2 次モード : $65 \mathrm{~Hz}$

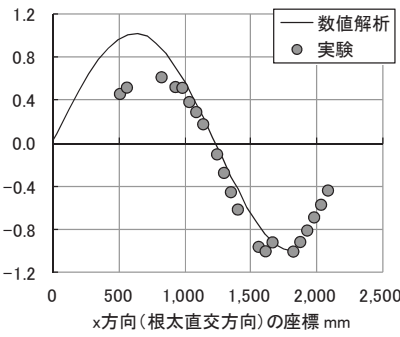

(b) 数值解析と実験のモード形状の比較（左：1次、右 : 2 次）

\section{図 12 現行床（軽角形鋼仕様）の振動固有值解析の結果}

部における形鋼への拘束の様子を示す。なお、床パネルの端部には、 リップのない軽溝形鋼が設置されており、モデル化の対象範囲は、 隣接するパネルの軽溝形鋼までとしている。

\subsection{2. 解析結果}

図 $12(\mathrm{a})$ に、振動固有值解析の結果として、1 次と 2 次モードの振 動数と形状を示す。また同図(b)に、モード形状について、本節の解 析と 2.3.の実験の結果を比較して示寸。同図には、根太スパン方向 の中央部の断面の振幅として、同図(a)中の B-B' 断面にお括面材 の振幅を示している。図の縦軸は、実験結果と解析結果のそれぞれ において床中央部の振幅を 1 として基準化した值を、横軸は床端部 を 0 とする場合の B-B' 断面の各計測点の $\mathrm{x}$ 方向の座標を示す。

同図と図 10 から、振動数とモード形状という 2 つの視点から、 本節の解析結果は 2.3.の実験結果と整合する傾向があると考えてい る。本節で示した以外のモデル化の方法として、例えば、面材のう ち、構造部材である硬質木片セメント板についてはその曲げ剛性と 質量を評価し、非構造部材である捨て合板や普通石膏ボードについ ては剛性を評価せずに質量のみを評価することなどが考えられる。 しかしながら、この場合には、1 次モードの振動数は $35 \mathrm{~Hz} 、 2$ 次モ ードは $39 \mathrm{~Hz}$ となり、実験結果とは整合しない。

以上から、本節で示したモデル化の方法により、適切なモデルを 構築できれば、実物件のスチールハウス床の振動性状を数值解析で 再現できると考えている。

\section{3. 根太と直交する部材を有する床の面外曲げ剛性}

本章では、前章の結果を踏まえ、床の弱軸方向の曲げ剛性の向上 を目指し、根太と直交する部材の追加による床の面外曲げ剛性の向 上の程度について数值解析により評価する。

\section{1. 評価対象の床}

図 13 に、評価対象の床の平面図と根太伏図を示す。評価対象の 物件は、3 階建、全 18 戸、ファミリー向けの共同住宅である。評価 対象の床は 2 階の 1 室で、同床は根太スパンが $3,640 \mathrm{~mm}$ 、根太直 交方向スパンが $5,460 \mathrm{~mm}$ である。根太と直交する部材を追加する
前の床は、2.1.の床と比較して、床根太が 1 方向に配置され、現行 のスチールハウスの標準的な仕様の一つを有するものである点は同 じであるが、二重床は有さず、捨て合板の厚さは $9 \mathrm{~mm}$ で、床根太 の断面が 2-235LCW12（2C-235x50x20x1.2）である点が異なる。 以下、根太と直交する部材を追加する前のこの仕様の床を「現行床 (リップ溝形鋼仕様)」と表記する。

図 14 に、図 13 の床の弱軸方向の曲价剛性の向上を目指して設置 するものとして、根太と直交する追加部材の立面図と断面図を示す。

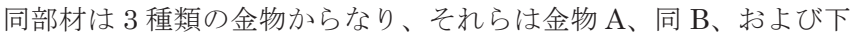
弦材である。金物 A と同 B は、高さが現行の床根太と同じ $235 \mathrm{~mm}$ であり、厚さ $1.2 \mathrm{~mm}$ の冷間成形材の組合せで構成される。金物 $\mathrm{B}$ は、同 $\mathrm{A}$ とは異なり、910 mm ピッチで配置されている独立天井根 太 184LCW10（C-184x50x20x1.0）との干渉を回避するため、ウェ ブ部に開口を有している。下弦材は、金物 B の開口に伴って生じる と推測される曲げ剛性の部分的な低下を補うために設置し、断面は 89LCN16（C-89x40x12x1.6）とする。なお、これらの金物 A、B、 および下弦材は、金物と直交する部材を追加することの効果の確認 のために考案しており、やや特殊な仕様を有するものである。汎用 化にあたっては、製造性や施工性の向上の視点から仕様の改良を検 討してゆく必要があると考えている。

\section{2. 解析計画}

表 2 に、面外曲げ剛性の解析対象のケース一覧を示す。解析対象
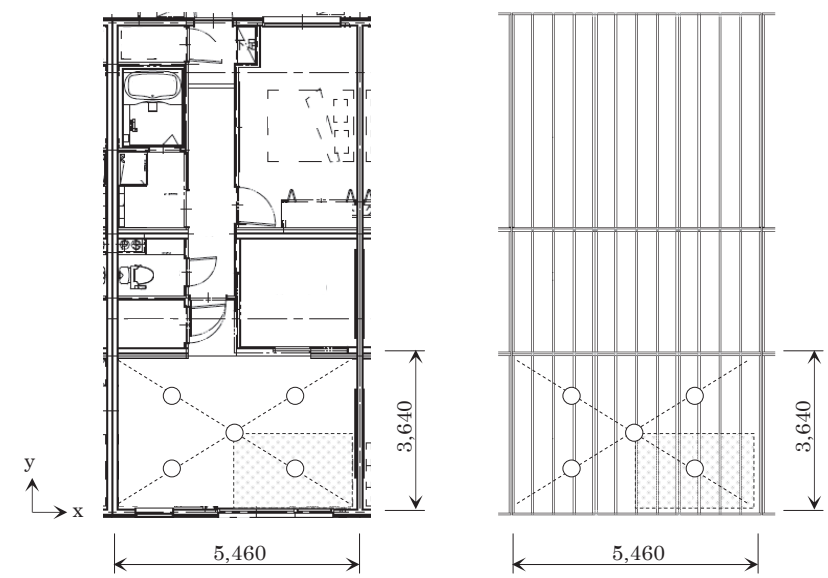

図 13 評価対象の床の平面図（左）と根太伏図（右）

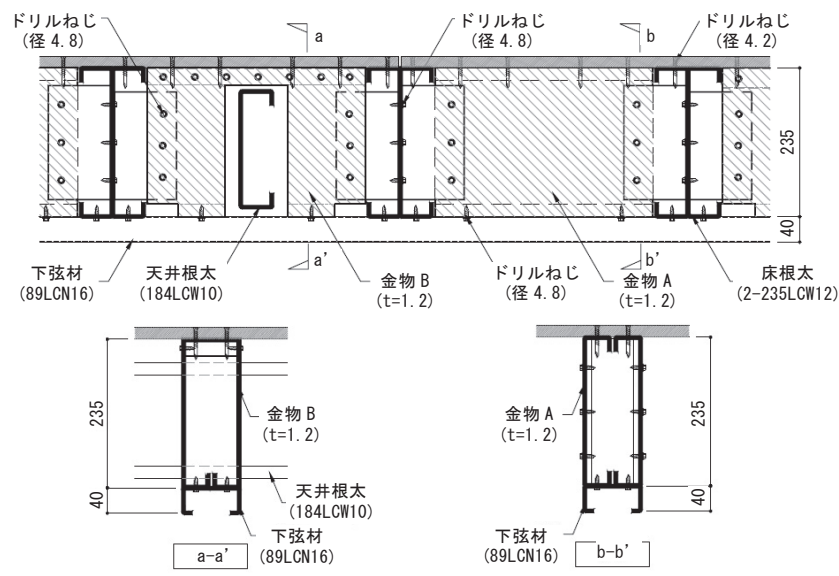

図 14 根太と直交する追加部材の立面図（上）と断面図（下） 
は、3 種類の金物の組合せと設置のピッチを変数として、現行仕様 （リップ溝形鋼仕様）を含む全 7 ケースと寸る。また図 15 に、現 行仕様、および根太と直交する金物を追加する仕様の解析モデルを 示す。同図中、面材は非表示としている。解析対象は、床面の対称 性を考慮し、床面の $1 / 4$ の範囲とする (図 13 中の網掛部)。材料物 性や使用要素、積層面材の評価方法、面材と形鋼の接合部の評価方 法などは 2.4. と同様とする。解析モデルの要素数は 8,000 20,000 程度としている。また床の境界条件は、図 15(a)中において、実線 部は上下を壁で支持されることを想定して、形鋼の上下フランジと ウェブの交線において鉛直方向の変位を拘束する。点線部には対称 条件を付与寸る。 2.4 と同様に、床パネルは 4 周を単純支持されて いる。

本解析モデルは、解析負荷軽減のため、前述の通り床面の $1 / 4$ の 範囲を対象として構築している。本モデルは、各種仕様のスチール 八ウス床の強軸方向と弱軸方向の曲げ剛性の評価を主目的としてお り、この評価において、本モデルは活用可能であると考えている。 一方、モデル内に対称条件を設定していることから、振動モードの 評価にあたっては、対称条件を付与している面を境界として位相が 反転するようなモードは評価できないといえ、この点には留意する 必要があると考えている。

図 16 に、面外曲げ剛性の評価方法を示す。同図には床全面のイ メージを示しているが、解析は前述のとおり床面の $1 / 4$ の範囲を対 象とする (図 16 中の網掛部)。根太スパン方向、および同方向と直 交する方向のそれぞれについて、中央線荷重と 2 辺単純支持の条件 における 3 点曲げを行い、荷重と変形の関係から各方向の曲げ剛性 $D_{x 、} D_{y}$ を算出する。図 16 中の $\triangle$ 印は、鉛直方向の変位を拘束して いることを示す。 3 点曲げの際には、図 16 中に示寸鉛直方向の変位 を拘束している部材のうち、支持辺ではない方の辺上の部材につい ては、同部材が曲げ剛性に影響を及ぼすことを避けるため、解析モ デルから同部材を除去して評価を行うこととする。以上の検討を材 料物性と幾何学変形ともに線形の条件下で実施する。なお、各ケー スについて、2.4. と同様に、振動固有值解析を行い、振動性状も調 查する。

\section{3. 解析結果}

表 3 に、解析結果として、強軸方向である根太スパン方向の曲げ 剛性 $D_{x 、}$ 弱軸方向である根太スパンと直交する方向の曲げ剛性 $D_{y}$ 面密度 $m$ と強軸のみ、弱軸のみ、または強軸と弱軸の両方の曲げ剛 性から算定 する基本インピーダンス $Z_{x} 、 Z_{y} 、 Z_{x y}$ 小およ゙ $1 \sim 3$ 次 のモードの振動数を示す。図 17 に、各ケースについて、3 点曲げ時 の床の根太スパン直交方向の変形として、図 16(b)中の F-F”' 断面の 変形を示す。同図中、ケース 3 は、ケース 4 と同様であったため省 略している。また図 18 に、各ケースの面密度当りの弱軸方向の曲 げ剛性を示す。同図における縦軸の值はケース 1 の值で基準化して 示す。図 19 に、各ケースの $1 \sim 3$ 次モードの形状を示す。

ここで、強軸と弱軸の曲げ剛性を評価する基本インピーダンスは、 文献 15)〜 17)などを参考に、下記の式(6)を用いて算出する。基本イ ンピーダンスのレベルは基準值を $1 \mathrm{~kg} / \mathrm{s}$ として算出する。

$$
Z_{x y}=8 \sqrt{m \cdot \sqrt{D_{x} \cdot D_{y}}}
$$

表 3 から、根太と直交する部材を設置することにより、弱軸方向
表 2 面外曲げ剛性の解析対称のケースー覧

\begin{tabular}{|c|c|c|c|c|c|c|c|}
\hline \multicolumn{2}{|r|}{ ケース } & \multicolumn{3}{|c|}{ 金物の種類 } & \multicolumn{3}{|c|}{ 金物のピッチ $\mathrm{mm}$} \\
\hline & 名称 & $\mathrm{A}$ & $\mathrm{B}$ & 下弦材 & 455 & 910 & 1,810 \\
\hline 1 & 現行 & - & - & - & - & - & - \\
\hline 2 & 直交-A-B-下-@ 455 & 0 & 0 & 0 & 0 & - & - \\
\hline 3 & 直交-A-B-下-@910 & 0 & 0 & 0 & - & O & - \\
\hline 4 & 直交-A-B-下-@1,810 & 1 & 0 & 0 & - & - & 0 \\
\hline 5 & 直交-A-下-@455 & 0 & - & 0 & 0 & - & - \\
\hline 6 & 直交-A-B-@455 & 0 & 0 & - & 0 & - & - \\
\hline 7 & 直交-下-@455 & - & - & 0 & 0 & - & - \\
\hline
\end{tabular}



(a) ケース 1



(c) ケース 3

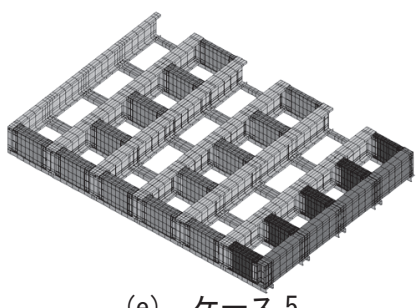

(e) ケース 5

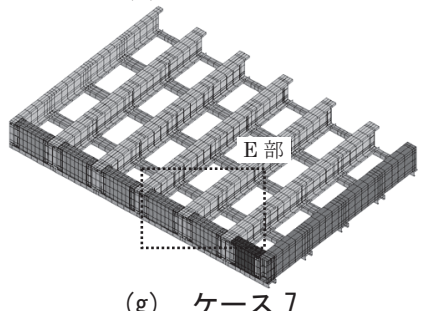

(g) ケース 7

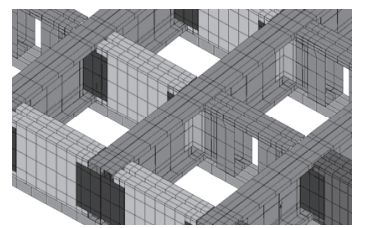

(i) D 部拡大

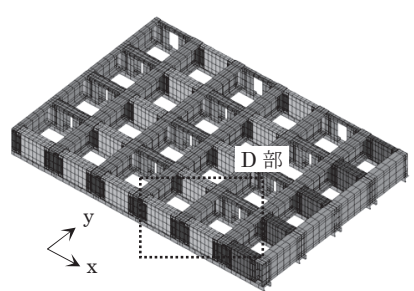

(b) ケース 2

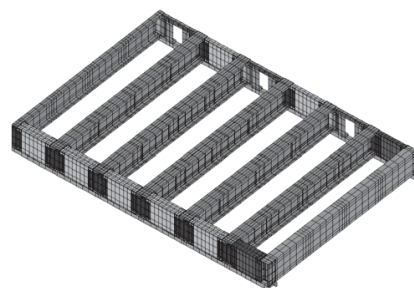

(d) ケース 4

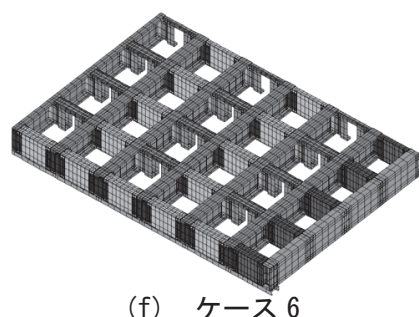

(f) ケース 6

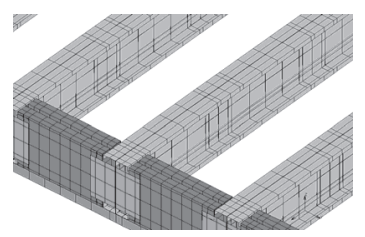

(h) C 部拡大

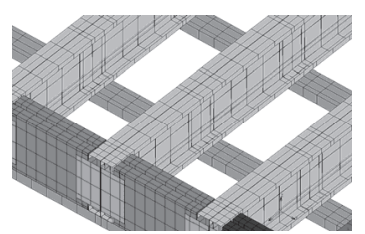

（j） E 部拡大
図 15 現行仕様 (リップ溝形鋼仕様)、および

根太と直交する金物を追加する仕様の解析モデル



(a) 根太スパン方向: $D_{x}$

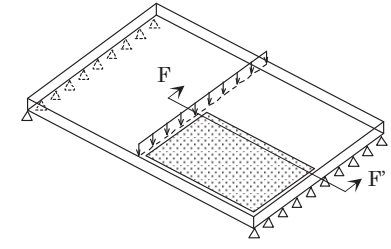

(b) 根太スパン直交方向 : $D_{y}$
図 16 面外曲げ剛性の評価方法 
表 3 現行仕様および根太と直交する金物を追加する仕様の解析結果の一覧

\begin{tabular}{|c|c|c|c|c|c|c|c|c|c|c|c|c|c|c|}
\hline & ケース & 面密度 & 曲げ岡小 & $(1,000 \mathrm{~m}$ & 幅当り） & & & 惎本インヒ & ーダン & & & & 振動娄 & \\
\hline No. & 名称 & & 強軸 & & & 強軸の厥 & & 弱軸の & & 強軸と弱 & 軸の & & & \\
\hline & & & & & 弱強 & のみを言 & 平価 & のみを & & 剛性を言 & & 1次 & 2次 & 3次 \\
\hline & & $\begin{array}{c}m \\
\mathrm{~kg} / \mathrm{m}^{2}\end{array}$ & $\begin{array}{c}D_{x} \\
\mathrm{~N} \cdot \mathrm{mm}^{2}\end{array}$ & $\begin{array}{c}D_{y} \\
\mathrm{~N} \cdot \mathrm{mm}^{2}\end{array}$ & $D_{y} / D_{x}$ & $\begin{array}{c}Z_{X} \\
\mathrm{~kg} / \mathrm{s}\end{array}$ & $\begin{array}{l}L_{Z x} \\
\mathrm{~dB}\end{array}$ & $\begin{array}{c}Z_{y} \\
\mathrm{~kg} / \mathrm{s}\end{array}$ & $\begin{array}{l}L_{Z y} \\
\mathrm{~dB}\end{array}$ & $\begin{array}{l}Z_{x y} \\
\mathrm{~kg} / \mathrm{s}\end{array}$ & $\begin{array}{r}L_{z x y} \\
\mathrm{~dB}\end{array}$ & $\begin{array}{l}f_{1} \\
\mathrm{~Hz}\end{array}$ & $\begin{array}{c}f_{2} \\
\mathrm{~Hz}\end{array}$ & $\begin{array}{c}f_{3} \\
\mathrm{~Hz}\end{array}$ \\
\hline 1 & 現行 & 51.5 & $8.8 \mathrm{E}+09$ & $3.1 \mathrm{E}+08$ & $\begin{array}{ll}1 / 27.8 \\
\end{array}$ & $5.4 \mathrm{E}+03$ & 74.6 & $1.0 \mathrm{E}+03$ & 60.2 & $2.3 \mathrm{E}+03$ & 67.4 & 48 & 57 & 79 \\
\hline 2 & 直交-A-B-下-@455 & 70.4 & 同上 & $5.8 \mathrm{E}+09$ & $1 / \quad 1.5$ & $6.3 \mathrm{E}+03$ & 76.0 & $5.1 \mathrm{E}+03$ & 74.2 & $5.7 \mathrm{E}+03$ & 75.1 & 46 & 120 & 237 \\
\hline 3 & 直交-A-B-下-@910 & 59.6 & 同上 & $3.2 \mathrm{E}+09$ & $\begin{array}{ll}1 / 2.7 \\
\end{array}$ & $5.8 \mathrm{E}+03$ & 75.2 & $3.5 \mathrm{E}+03$ & 70.9 & $4.5 \mathrm{E}+03$ & 73.1 & 47 & 102 & 192 \\
\hline 4 & 直交-A-B-下-@1,810 & 54.2 & 同上 & $1.4 \mathrm{E}+09$ & $\begin{array}{ll}1 / & 6.2 \\
\end{array}$ & $5.5 \mathrm{E}+03$ & 74.8 & $2.2 \mathrm{E}+03$ & 66.9 & $3.5 \mathrm{E}+03$ & 70.9 & 48 & 84 & 134 \\
\hline 5 & 直交-A-下-@455 & 63.5 & 同上 & $4.1 \mathrm{E}+09$ & $\begin{array}{ll}1 / & 2.1 \\
\end{array}$ & $6.0 \mathrm{E}+03$ & 75.5 & $4.1 \mathrm{E}+03$ & 72.2 & $4.9 \mathrm{E}+03$ & 73.9 & 48 & 84 & 153 \\
\hline 6 & 直交-A-B-@ 455 & 66.4 & 同上 & $4.6 \mathrm{E}+08$ & $\begin{array}{ll}1 / & 18.9 \\
\end{array}$ & $6.1 \mathrm{E}+03$ & 75.7 & $1.4 \mathrm{E}+03$ & 62.9 & $2.9 \mathrm{E}+03$ & 69.3 & 43 & 56 & 87 \\
\hline 7 & 直交-下-@455 & 55.5 & 同上 & $3.7 \mathrm{E}+08$ & $1 / 23.7$ & $5.6 \mathrm{E}+03$ & 74.9 & $1.1 \mathrm{E}+03$ & 61.2 & $2.5 \mathrm{E}+03$ & 68.1 & 47 & 56 & 83 \\
\hline
\end{tabular}

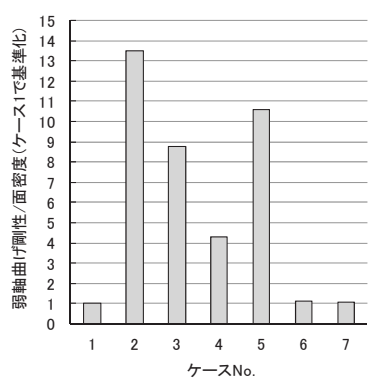

図 18 弱軸剛性の比較

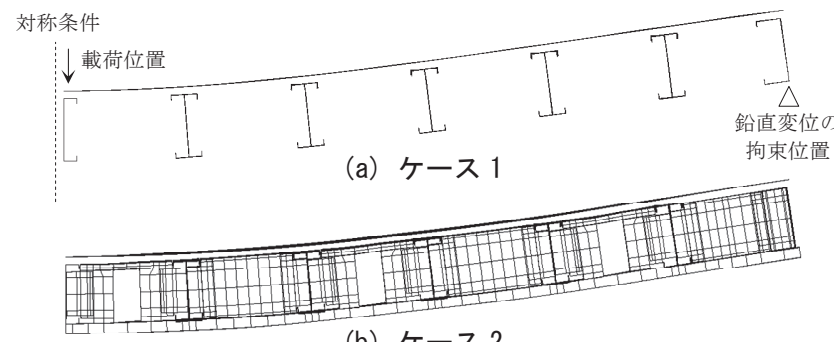

(b) ケース 2

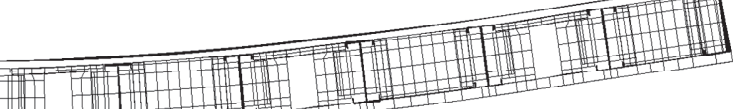

(c) ケース 4

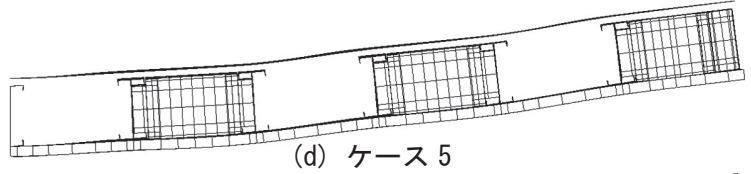

(d) ケース 5

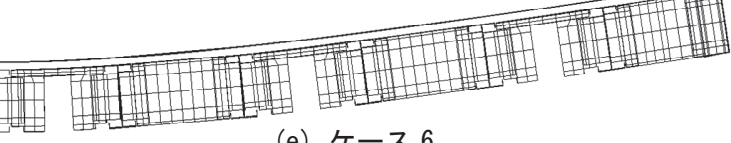

(e) ケース 6

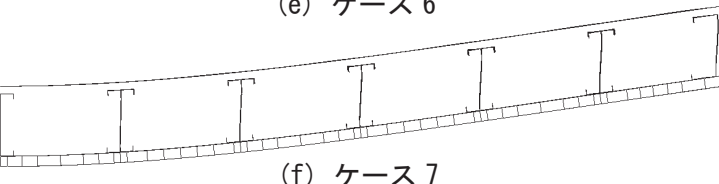

(f) ケース 7

図 173 点曲げ時の床の根太スパン直交方向の変形の様子



1 次: $48 \mathrm{~Hz}$

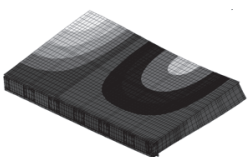

2 次 : $57 \mathrm{~Hz}$

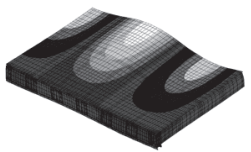

3 次 : $79 \mathrm{~Hz}$

(a) ケース 1
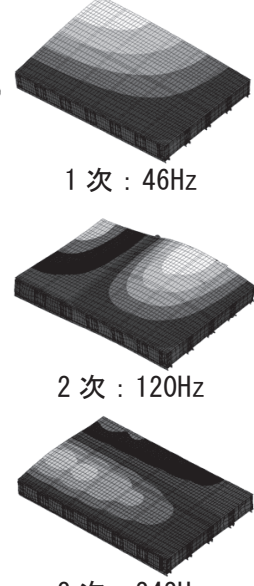

(b) ケース 2

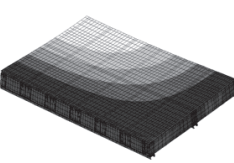

1 次 : $47 \mathrm{~Hz}$

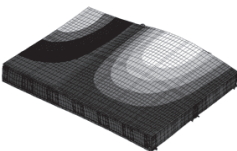

2 次 : $102 \mathrm{~Hz}$

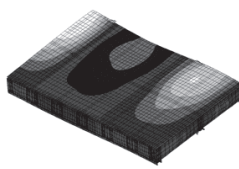

3 次: $192 \mathrm{~Hz}$

(c) ケース 3

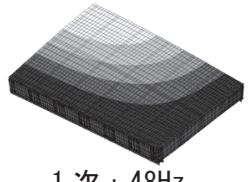

1 次 : $48 \mathrm{~Hz}$

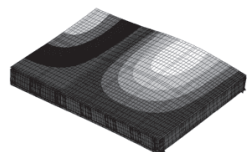

2 次 : $84 \mathrm{~Hz}$

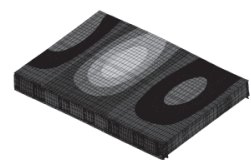

3 次 : $134 \mathrm{~Hz}$

(d) ケース 4

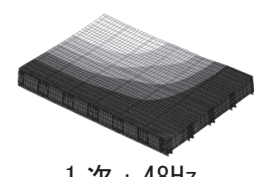

1 次 : $48 \mathrm{~Hz}$

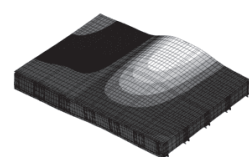

2 次 : $84 \mathrm{~Hz}$

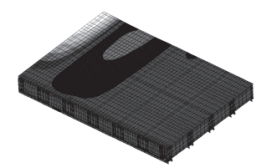

3 次: $153 \mathrm{~Hz}$

(e) ケース 5

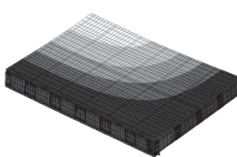

1 次 : $43 \mathrm{~Hz}$

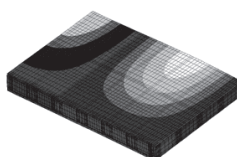

2 次 : $56 \mathrm{~Hz}$

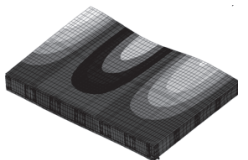

3 次 : $87 \mathrm{~Hz}$

(f) ケース 6

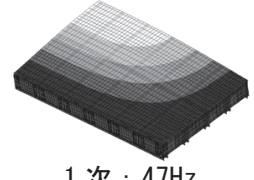

1 次 : $47 \mathrm{~Hz}$
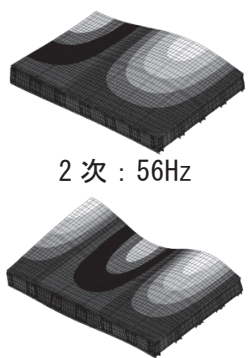

3 次 : $83 \mathrm{~Hz}$

(g) ケース 7

図 19 現行仕様、および根太と直交する金物を追加する仕様の振動固有値解析の結果

の曲げ剛性が向上しており、例えば 3 種類の金物を根太と同様の $455 \mathrm{~mm}$ ピッチで密に設置するケース 2 では、現行床（リップ溝形 鋼仕様）のケース 1 と比較して、弱軸方向の曲げ剛性が 18 倍程度 となり、強軸方向に対する弱軸方向の曲げ剛性の比率も $1 / 1.5$ 程度 まで向上していることがわかる。一方、金物 $\mathrm{A}$ と金物 $\mathrm{B}$ のみを追加 設置するケース 6 や、下弦材のみを追加設置するケース 7 では、弱 軸方向の曲げ剛性の向上の程度は小さいことがわかる。

これは、金物 $\mathrm{A}$ とウェブに開口のある金物 B だけ、あるいは下弦 材を設置するだけのケースでは、部材に作用寸る曲げモーメントと せん断力に対して各部材が分担して抵抗するような構成となってい ないため、軽量で高剛性といった特徴を有する例えばサンドイッチ パネルや $\mathrm{H}$ 形鋼などとは異なり、追加部材の重量ほどには剛性が向
上されないものと推察する。図 17 から、下弦材のみを追加設置す るケース 7 では、ケース 2 などとは異なり、床面材と下弦材の曲率 中心が芯材のそれとは一致しない傾向があることがわかる。同ケー スでは、一見、サンドイッチパネル状に部材が存在するものの、床 面材と下弦材がそれぞれ独立した部材として作用力に抵抗している ため、剛性向上の視点では効果の得られにくい部材構成になってい ると考えられる。

なお、図 18 から、面密度当りの弱軸方向の曲げ剛性という視点 では、ケース 2 が最も効率良く、ついでケース 5 となっている。ケ

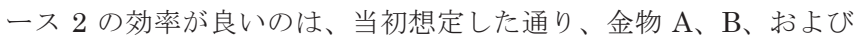
下弦材により、面材や下弦材、および金物 A、B といった芯材が、 サンドイッチパネル状に、効率良く作用力に抵抗できているためと 
推察する。また、次いでケース 5 が高効率となったのは、金物 $\mathrm{B}$ は 下弦材とあわせて設置すれば比較的効率の良い剛性向上の手段とな るが、独立天井を回避する開口を有していることにより、同金物を 設置しなくてもある程度の効率が確保されたためと考えている。

また図 19 から、根太と直交する部材の追加設置により、1 次モー ドの振動数にはあまり変化がないものの、2 次モード以降の振動数 は向上する傾向があることがわかる。これは、2.3.や 2.4.で確認し ているが、1 方向の根太を有する現行のスチールハウス床では、根 太スパン方向と直交する方向に腹が増えてモードが高次化する傾向 があることから、根太と直交する部材の追加によりこのモードの剛 性が高まって、振動数が向上していると推察する。3 種類の金物を 根太と同様の $455 \mathrm{~mm}$ ピッチで密に設置するケース 2 では、3 次モ ードにおいて、根太スパン方向と直交する方向ではなく、根太スパ ン方向に腹が増えてモードが高次化しており、根太スパン方向と直 交寸る方向の曲げ剛性が十分に大きいため、モード形状の高次化の 傾向が他のケースと異なっているといえる。

以上から、独立天井根太を有寸る現行のスチールハウス床におい て、床根太を 2 方向化して床全体の曲げ剛性を向上するには、例え

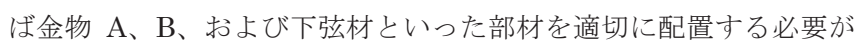
あると考えている。また、前記のような金物を選定すれば、根太ス パン方向の曲げ剛性と近しい程度まで、同方向と直交する方向の曲 げ剛性を向上できる可能性があるといえる。

\section{4. 根太と直交する部材を有する床の重量床衝撃音の遮断性}

本章では、前章までの結果を踏まえ、実物件を対象に、根太と直 交する部材を追加して曲げ剛性を向上した床の重量床衝撃音の遮断 性を実験により評価する。

\section{1. 評価対象の床}

図 20 に評価対象の物件の外観、図 21 に調查時の様子、および図 22 に評価対象の床の施工時の様子を示す。本章で評価する物件や床 の平面寸法などは 3. と同じものとする。評価対象の床の仕様は、表 4 のケース 1 (現行仕様) とケース 2 (根太と直交する方向に 3 種類 の金物を $455 \mathrm{~mm}$ ピッチで配置) の 2 種類とする。

\section{2. 実験計画}

評価は施工が完了した時点で実施する。加振と計測は JIS A 1418-2 に準拠して行う。加振源は標準重量衝撃源（タイヤ）とし、 加振点と計測点は、床中央点と対角線の 4 等分点 4 点からなる 5 点 とする (図 13 中の○部)。各計測点の結果をエネルギー平均し、各 加振点の結果を算術平均して重量床衝撃音の遮断性を評価する。

\section{3. 実験結果}

図 23 に、現行仕様の床、および根太と直交する部材を有する床 の重量床衝撃音の遮断性の評価結果を示す。

同図から、根太と直交する部材を有する床は、現行仕様の 1 方向 根太床と比較して、重量床衝撃音の遮断性が向上していることがわ かる。JIS A 1419-2 の等級曲線を参照すると、両者ともにおいて $63 \mathrm{~Hz}$ 帯域が衝撃音の遮断性能の決定周波数となっており、同帯域 の音圧レベルは、前者は $88.6 \mathrm{~dB}$ であるのに対し、後者は $83.3 \mathrm{~dB}$ で あり、 $5.3 \mathrm{~dB}$ の改善が見られることがわかる。

また同図と表 3 から、音圧レベルの差異が $5.3 \mathrm{~dB}$ であるのに対し、 強軸の曲げ剛性のみを評価する場合の基本インピーダンスレベルの

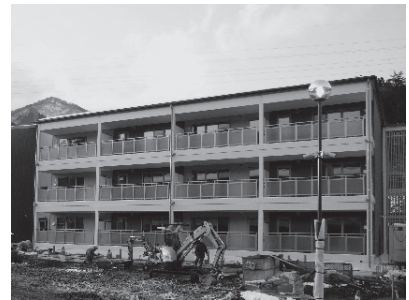

図 20 評価対象の外観

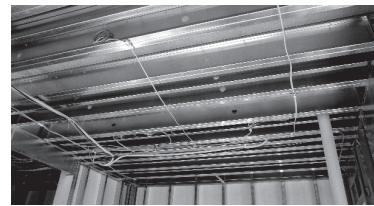

(a) 表 3 ケース 1

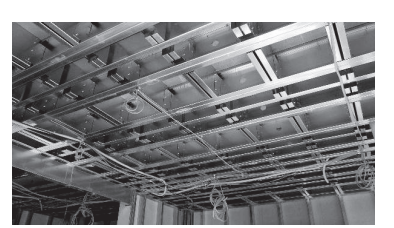

(b) 表 3 ケース 2 (下弦材設置前) 図 22 評価対象床の施工状況

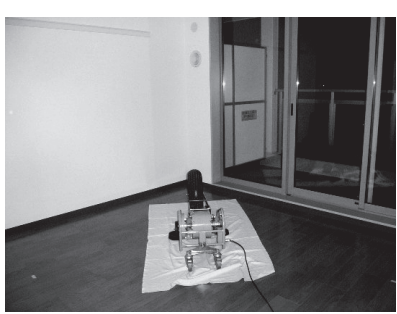

図 21 調査時の様子

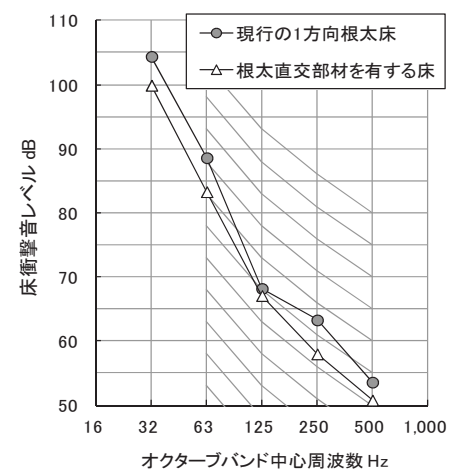

図 23 対策前後の床の 重量床衝撃音遮断性の比較
差異は $1.4 \mathrm{~dB}$ 、弱軸のみを評価する場合は $14.0 \mathrm{~B}$ 、強軸と弱軸の曲 げ剛性を評価する場合の差異は $7.7 \mathrm{~dB}$ となっており、仕様変更前後 の床の強軸や弱軸の曲げ剛性の差異をそれぞれ単独で評価するより は、式(6)に従って強軸と弱軸の両方の曲げ剛性の差異を評価する方 が、基本インピーダンスレベルの差異が音圧レベルの差異に近いこ とがわかる。

以上から、スチールハウス床において、適切な金物を選定し、根 太スパン方向と直交方向の曲げ剛性を向上すれば、重量床衝撃音の 遮断性を向上できる場合がある。また、本報で検討したケースにお いては、基本インピーダンスレベルの向上の程度の評価において、 仕様変更前後の床の強軸や弱軸の曲げ剛性の差異をそれぞれ単独で 評価するよりは、式(6)に従って床の強軸と弱軸の両方の曲げ剛性の 差異を評価する方が、重量床衝撃音の遮断性の向上の程度に近しい 值を得ることができるといえる。

\section{5. まとめ}

スチールハウスのような 1 方向に根太が配される床構造において、 重量床衝撃音の遮断性を向上するため、文献 8)や9)では、床の面外 の曲げ剛性が強軸方向と弱軸方向で異なる点を踏まえ、根太床の部 材構成に注目して、根太スパン方向と直交する方向にころび止めや ふれ止めを設置する方法が検討されている。しかしながら、これら の文献においては、検討対象の部材構成の範囲内では、重量床衝撃 音の遮断性を向上する程度まで弱軸方向の曲げ剛性を向上すること は困難であることが定性的に示されるにとどまっていた。

そこで本報では、これらの知見を活用しつつ、根太と直交する部 材を追加することによる重量床衝撃音の遮断性の向上の可能性を探 索すべく、現行床（軽角形鋼仕様、リップ溝形鋼仕様）の性能の調 查結果を踏まえ、根太と直交する部材と床の弱軸方向の面外曲げ剛 性の関係を定量的に調查し、対策を施した床の性能の評価を行って、 
衝撃音の遮断性の向上に必要な部材構成の検討に取組んだ。得られ た知見を以下に示す。

1）現行仕様のスチールハウス床の重量床衝撃音の遮断性の向上に は、 $63 \mathrm{~Hz}$ 帯域の性能の向上が必要である。現行の独立天井や乾 式二重床の設置により $4 \sim 8 \mathrm{~dB}$ の重量床衝撃音レベルの改善が得 られている一方、空気層をばねとする共振の影響は見られていな いことから、前記帯域の性能向上には、少なくとも空気層をばね と寸る振動系の共振回避によることは難しいといえ、例えば天井 や二重床の防振化や本報で検討する床の高剛性化などの改良を検 討する必要があるといえる。

2）現行仕様のスチールハウス床は、実験の結果として、重量床衝 撃音の遮断性の決定周波数となる $63 \mathrm{~Hz}$ 帯域において、根太スパ ン方向と直交する方向に腹が増えて振動する傾向がある。この振 動は、スチールハウス床が曲げ剛性について異方性を有するため に生じると考えられる。またこの実験結果の傾向は、適切なモデ ルを設定すれば、数值解析によっても再現できる。

3）スチールハウス床において、弱軸である根太スパンと直交する 方向の曲げ剛性は、適切な部材を選定することで、強軸である根 太スパン方向の曲渆性と同程度まで向上寸ることができる。

4）スチールハウス床において、適切な部材を選定して、根太スパ ン方向と直交する方向の曲げ剛性を向上できれば、重量床衝撃音 の遮断性を向上できる場合がある。

5）本報で示した実験結果 1 例では、根太と直交する部材を設置す る前後のスチールハウス床の重量床衝撃音の遮断性の差異を評価 する場合、基本インピーダンスレベルの向上の程度の評価におい て、仕様変更前後の床の強軸や弱軸の曲げ剛性の差異をそれぞれ 単独で評価するよりは、式(6)に従って強軸と弱軸の両方の曲げ剛 性の差異を評価する方が、衝撃音の実験值の差異に近しい值を得 ることができた。この傾向の一般性の確認は、実験例を増やして 調查してゆく必要があり、今後の課題である。

\section{参考文献}

1) Steel Framing Alliance: Cold-Formed Steel Design Manual, 2013

2）日本鉄鋼連盟：薄板軽量形鋼造建築物設計の手引き - 第 2 版-，技報堂出 版, 2014

3）金子昇, 二宮淳, 関根秀生, 井上勝夫, 木村翔: $\mathrm{KC}$ 型スチールハウスの重 量床衝撃音遮断性能の課題抽出 - スチールハウスの諸性能に関する研究 その 18-, 日本建築学会大会学術講演梗概集, D-1, 環境工学 I, pp.221-222, 1998.9

4）関根秀生, 金子昇, 二宮淳, 井上勝夫, 木村翔: $\mathrm{KC}$ 型スチールハウスの重 量床衝撃音遮断性能の向上 - スチールハウスの諸性能に関寸る研究 その 19-, 日本建築学会大会学術講演梗概集, D-1, 環境工学 I, pp.223-224, 1998.9

5）杉本明男：粒状体衝撃ダンパによるスチールハウス重量床衝撃音の低減， 日本建築学会大会学術講演梗概集, D-1, 環境工学 I, pp.225-226, 2002.8

6) 荒木嘉昭, 横道勲, 井上順吉：粉粒体衝撃ダンパ-垂直振動, 片側衝突時 の特性-, 日本機械学会論文集(C 編), 49 巻, 442 号, pp.945-951, 1983.6

7) L. Salvino, P. Dupont, J.G. McDaniel, Evaluation of Granular-fill Damping in Shock Loaded Box Beams, Proceedings of 69th Shock and Vibration Symposium, 1998.10

8）太田克也，関根英生，二宮淳，藤本隆裕，杉本明男，吉村純一，井上勝夫： スチールハウスの重量床衝撃音遮断性能（1）実験方法と供試床の仕様 -KC 型スチールハウスの諸性能に関寸る研究 その 20-, 日本建築学会大会 学術講演梗概集, D-1, 環境工学 I, pp.187-188, 1999.9

9）関根秀生，太田克也，二宮淳，藤本隆裕，杉本明男，吉村純一，井上勝夫： スチールハウスの重量床衝撃音遮断性能 実験結果と検討 -スチールハウ
スの諸性能に関する研究 その $21^{-}$, 日本建築学会大会学術講演梗概集, D-1, 環境工学 I, pp.189-190, 1999.9

10）日本建築学会：実務的騒音対策指針（第二版），技報堂出版，2000

11) F. X. Xin, T. J. Lu, Analytical modeling of sound transmission through clamped triple-panel partition separated by enclosed air cavities, European Journal of Mechanics, A/Solids 30 (6), pp.770-782, 2011

12）長松昭男：モード解析入門，コロナ社, 1993

13）鈴木秀三，井原行孝，藤野栄一：木造根太床の鉛直振動特性に関する実 験的研究, 日本建築学会計画系論文集, 第 556 号, pp.9-15, 2002.6

14) MSC.Software: Marc Manual -Vol. A Theory and User Information-

15）渡辺大助，井上勝夫，鈴木俊男：異方性スラブの振動特性に関する基礎 的検討, 日本建築学会環境系論文集, 第 77 巻, 680 号, pp761-769, 2012.10

16）鈴木俊男, 井上勝夫：異方性スラブの振動特性に関寸る検討 その 3 基 本インピーダンスの算定, 日本建築学会大会学術講演梗概集, D-1, 環境工 学 I, pp161-162, 2010.7

17）日本建築学会：建物の床衝撃音防止設計, 2009.11 


\title{
EVALUATION OF HEAVY-WEIGHT FLOOR IMPACT SOUND INSULATION PERFORMANCE OF COLD-FORMED STEEL FRAMED HOUSE WITH LATTICE-ARRAYED FLOOR JOISTS
}

\author{
Nariaki NAKAYASU ${ }^{* 1}$, Hiroyuki KAIBARA ${ }^{* 1}$, Koji HANYA*2 \\ and Daiji TAKAHASHI ${ }^{* 3}$ \\ ${ }^{* 1}$ Nippon Steel \& Sumitomo Metal Corporation, M.Eng. \\ *2 Nippon Steel \& Sumitomo Metal Corporation, Dr.Eng. \\ ${ }^{*}$ Prof., Dept. of Architecture and Architectural Engineering, Kyoto University, Dr.Eng.
}

The number of cold-formed steel framed houses is increasing and they tend to be built as apartment houses rather than detached houses. Along with this trend, heavy-floor impact sound insulation performance of the houses is expected to be improved. In order to meet this expectation, experimental test and numerical analysis are carried out, using the really-constructed houses as specimens. The results indicate, 1) in order to improve the heavy-floor impact sound insulation performance of cold-formed steel framed houses, sound pressure in a frequency band of $63 \mathrm{~Hz}$ has to be reduced, 2) floors of cold-formed steel houses tend to vibrate in a perpendicular direction to floor joists axis in the low-ranged frequency band, which is caused by the anisotropy of floor bending stiffness, 3) considering the vibrating mode shape, to improve sound insulation performance, it seems one of the solutions to increase the floor bending stiffness of weak axis, and 4) the possibility of the suggested solution is confirmed through the on-site test. 